\title{
Pengaruh Literasi Digital Guru dan Manajemen Pembelajaran Terhadap Minat Belajar Peserta Didik di SMA Pelita Rantepao
}

\author{
Zeth Rodo Landa ${ }^{1}$, Tarsicius Sunaryo ${ }^{2}$, Hotner Tampubolon ${ }^{3}$ \\ 1, 2, 3 Universitas Kristen Indonesia, Jl. Mayjen Sutoyo, Cawang, Kec. Keramat Jati, Kota Jakarta Timur, DKI Jakarta \\ zethrodo@gmail.com
}

\begin{abstract}
This study aims to 1) analyze the effect of teacher digital literacy on students' learning interest in SMA Pelita Rantepao; 2) Analyzing the effect of learning management on students' learning interest in SMA Pelita Rantepao; 3) Analyze digital literacy skills and "learning management in explaining the learning interest of students at SMA Pelita Rantepao. This type of research is ex post facto research. The sampling technique used saturated sampling, namely all teachers at SMA Pelita Rantepao. The research model consisted of digital literacy (X1), learning management (X2) as the independent variable, and students' interest in learning (Y) as the dependent variable. The data collection technique is done by using a questionnaire that is distributed directly. The method used in analyzing the data is correlation analysis and multiple regression with the help of the SPSS application version 25. The results show that: 1) Teacher digital literacy (X1) affects students' interest in learning (Y at SMA Pelita Rantepao, North Toraja Regency. digital teacher (X1) towards students 'interest in learning by $60.4 \%$; 2) Learning management (X2) affects students' interest in learning (Y). The influence of learning management on students' interest in learning is $55.6 \%$; 3) The model (digital literacy (X1) and learning management (X2)) can explain variations in students' interest in learning (Y) by $66.1 \%$.
\end{abstract}

Keywords: Digital literacy, interest in learning

\begin{abstract}
Abstrak
Penelitian ini bertujuan untuk 1) Menganalisis pengaruh literasi digital guru terhadap minat belajar peserta didik di SMA Pelita Rantepao; 2) Menganalisis pengaruh manajemen pembelajaran terhadap minat belajar peserta didik di SMA Pelita Rantepao; 3) Menganalisis kemampuan literasi digital dan "manajemen pembelajaran dalam menjelaskan minat belajar peserta didik di SMA Pelita Rantepao. Jenis penelitian ini merupakan penelitian expost facto. Teknik penentuan sampel menggunakan sampling jenuh, yaitu semua guru di SMA Pelita Rantepao. Model penelitian terdiri dari literasi digital (X1), manajemen pembelajaran (X2) sebagai varabel bebas, dan minat belajar peserta didik (Y) sebagai variabel terikat. Teknik pengumpulan data dilakukan dengan menggunakan kuesioner yang dibagikan secara langsung. Metode yang digunakan dalam menganalisis data adalah analisis korelasi dan regresi berganda dengan bantuan Aplikasi SPSS versi 25. Hasil Penelitian menunjukkan bahwa: 1) Literasi digital guru (X1) mempengaruhi minat belajar peserta didik (Y di SMA Pelita Rantepao Kabupaten Toraja Utara. Besar pengaruh literasi digital guru (X1) terhadap minat belajar peserta didik sebesar 60,4\%; 2) Manajemen pembelajaran (X2) mempengaruhi minat belajar peserta didik(Y). Besar pengaruh manajemen pembelajaran terhadap minat belajar peserta didik sebesar 55,6\%; 3) Model (literasi digital (X1) dan manajemen pembelajaran(X2)) dapat menjelaskan variasi pada minat belajar peserta didik (Y) sebesar 66,1\%.
\end{abstract}

Kata kunci: Literasi digital, minat belajar

Copyright (c) 2021 Zeth Rodo Landa, Tarsicius Sunaryo, Hotner Tampubolon

$\triangle$ Corresponding author: Zeth Rodo Landa

Email Address: zethrodo@gmail.com_(J1. Mayjen Sutoyo, Cawang, Kec. Keramat Jati, Jakarta Timur, DKI Jakarta)

Received 17 Februari 2021, Accepted 26 Maret 2021, Published 26 Maret 2021

\section{PENDAHULUAN}

Mutu pendidikan di Indonesia merupakan salah satu permasalahan besar yang harus menjadi prioritas untuk segera mendapatkan perhatian pemerintah. Salah satu indikator rendahnya mutu pendidikan kita dapat dilihat dari laporan hasil survey PISA-OECD yang dirilis pada tanggal 03 Desember 2019. PISA memberikan evaluasi bagi sistem pendidikan menengah pada tiga aspek, yaitu matematika, sains, dan literasi. Hasil survey ini menempatkan Indonesia berada pada peringkat yang 
sangat rendah yaitu menempati posisi ke 71 yang diikuti oleh 78 negara yang sebagaimana dikutip pada laman resmi OECD.

Salah satu faktor yang turut memberikan pengaruh bagi mutu pendidikan adalah adanya minat belajar dari para peserta didik. Hasil penelitian yang dilakukan oleh Sirait (2016:41), Rozikin, dkk. (2018:81) menunjukkan bahwa minat belajar memberikan konstribusi yang signifikan terhadap prestasi belajar. Peserta didik yang memiliki minat belajar yang kuat akan menunjukkan minat yang kuat dalam mempelajari berbagai hal, berpartisipasi aktif dalam setiap kegiatan pembelajaran, dan memiliki semangat berprestasi. Begitu pula dengan minat belajar yang rendah juga akan berdampak pada rendahnya minat belajar. Penelitian yang dilakukan oleh Haryati, dkk (2019: 133) menunjukkan bahwa minat belajar peserta didik sebagian besar berada pada kategori sedang, namun pada kemampuan berpikir kritis masih berada pada kategori yang sangat rendah. Rendahnya kemampuan berpikir kritis dapat disebabkan oleh penyelenggaraan kegiatan pembelajaran yang belum mengajak peserta didik untuk membiasakan diri berpikir tingkat tinggi (Higher Order Thinking Skills) tetapi masih terfokus pada kemampuan menghafal materi pelajaran. Oleh karena itu sangat penting bagi guru untuk merancang kegiatan pembelajaran dengan baik dan dapat menyampaikan materi pelajaran yang menarik sehingga dapat meningkatkan minat belajar peserta didik.

Guru sebagai pihak yang terlibat secara langsung dalam kegiatan pembelajaran memiliki peranan yang sangat besar dalam upaya meningkatkan mutu pendidikan. Mereka harus dapat merencanakan dan menyelenggarakan kegiatan belajar mengajar yang memfasilitasi keterlibatan peserta didik secara aktif, inovatis, memberikan kesempatan yang seluas-luasnya kepada peserta didik untuk mengembangkan kreativitas, dan menciptakan suasana belajar yang menyenangkan. Menurut Slamet (2017:116) bahwa guru yang kurang menguasai materi pelajaran, tidak menggunakan metode belajar yang bervariasi, dan tidak dapat menyelenggarakan pembelajaran yang menarik akan cenderung membosankan dan mengurangi konsentrasi peserta didik.

Salah satu upaya yang dapat dilakukan oleh guru dalam menarik minat peserta didik adalah mengintegrasikan teknologi digital atau dikenal juga dengan teknologi informasi dan komunikasi (TIK) dalam kegiatan pembelajaran. Hal ini penting dilakukan mengingat peserta didik sekarang adalah generasi milenial (Millennial Generation). Peserta didik generasi milenial berada pada era revolusi digital atau revolusi industri 4.0 juga dikenal dengan distruptive innovation. Era ini ditandai dengan pergeseran teknologi khususnya dalam bidang teknologi informasi dan komunikasi (TIK) dimana terjadi penggabungan antara teknologi digital, akses internet dan industri konvensional. Teknologi ini didukung oleh kehadiran berbagai macam gawai seperti telepon pintar (smartphone), komputer, laptop, dan ketersediaan akses internet dari berbagai provider. Menurut Hidayatullah, dkk (2018:241) dari Universitas Merdeka Malang dalam artikelnya menjelaskan bahwa generasi milenial memiliki karakter yang sangat familiar dengan teknologi digital sehingga sangat tepat untuk menggunakan media digital dalam kegiatan pembelajaran. 
Perkembangan teknologi digital saat ini harus dilihat oleh guru sebagai sebuah peluang dan memanfaatkannya dalam upaya meningkatkan minat belajar peserta didik. Saat ini hampir semua guru dan siswa memiliki perangkat pendukung TIK seperti smartphone, laptop, atau PC dengan dengan kemudahan dalam mengakses internet. Berdasarkan hasil survey yang dipaparkan pada kanal websindo.com (2019) bahwa jumlah smartphone di Indonesia lebih banyak dari jumlah penduduknya yaitu sekitar 133\%, sedangkan penggunaan smartphone untuk mengakses internet sebesar $60 \%$ dan PC sebanyak 22\%. Peluang ini dapat digunakan oleh guru untuk merancang pembelajaran dengan baik, mengakses sumber-sumber belajar yang menarik baik berupa teks, audio, atau video yang dapat digunakan pada saat proses pembelajaran sehingga proses pembelajaran tidak monoton tetapi menjadi lebih menarik sehingga peserta didik dapat lebih berminat dalam belajar. Guru juga dapat mengkreasi bahan ajar mereka menjadi sebuah animasi atau video menarik dan membagikannya kepada peserta didik sehingga peserta didik dapat mengakses materi pelajaran tersebut kapan saja mereka inginkaan. Dengan "kreativitas guru yang tinggi untuk menyusun dan mempersiapkan bahan ajar yang menarik maka diharapkan dapat meningkatkan minat belajar peserta didik dapat meningkat.

Untuk dapat memanfaatan teknologi digital maka guru membutuhkan kemampuan literasi digital yaitu kemampuan dalam hal pengetahuan dan keterampilan menggunakan perangkat digital seperti smartphone, PC, atau laptop serta dapat mengoperasikan aplikasi pendukung sehingga dapat membantu guru dalam merancang pembelajaran yang berkualitas.

Pemanfaatan teknologi digital dalam bidang pendidikan telah menjadi bagian penting dari pengembangan kompetensi guru. Di dalam Permendiknas No. 16 Tahun 2007, dijelaskan bahwa salah satu kompetensi pedagogik seorang guru adalah mampu memanfaatkan perangkat TIK / digital bagi kepentingan pembelajaran. Hal itu sejalan dengan UU No. 14 Tahun 2005 tentang Guru dan Dosen yang mengamanatkan seorang guru untuk dapat memanfaatkan perangkat TIK untuk kepentingan penyelenggaraan kegiatan pembelajaran bagi peserta didik.

Kehadiran teknologi digital tidak serta merta diterima dan digunakan oleh guru dalam proses pembelajaran. Ada beberapa alasan sehingga kalangan tertentu guru masih gagap teknologi dan tidak mengambil manfaat dan menggunakannya dalam kegiatan pembelajaran. Styaningrum (2016:8), dalam sebuah artikelnya menjelaskan bahwa hambatan guru dalam pemanfaatan teknologi digital adalah fakor umur dimana guru-guru yang sudah tua tidak memiliki motivasi lagi dalam mempelajari hal-hal baru. Faktor lain yaitu keterbatasan waktu untuk belajar dan kurangnya rasa kepercayaan diri dalam menggunakan teknologi digital untuk pembelajaran.

Pembelajaran yang membangkitkan minat peserta didik juga ditentukan oleh kekuatan manajemen pembelajaran guru. Tugas guru sebagai seorang manajer harus dapat membuat perencanaan, melakukann pengorganisasian, melaksanakan proses pembelajaran, melaksanakan penilaian hasil belajar, serta pengawasan proses pembelajaran sebagaimana diatur dalam PP No. 13 tahun 2015. Selain itu guru harus mampu memberikan motivasi yang baik kepada peserta didik sehingga dapat menumbuhkan minat belajar mereka dan mereka belajar dengan penuh kesadaran dan ketekunan tanpa 
adanya paksaan. Berdasarkan pemaparan tersebut maka peneliti tertarik untuk melakukan penelitian tentang pengaruh Literasi Digital dan Manajemen Pembelajaran terhadap Minat Belajar Peserta Didik Di SMA Pelita Rantepao, Kabupaten Toraja Utara.

Penelitian ini sangat penting dilakukan mengingat minat belajar peserta didik di SMA Pelita Rantepao masih dalam kategori rendah. Identifikasi awal peneliti menemukan bahwa peserta didik di SMA Pelita Rantepao belum sepenuhnya aktif terlibat dalam kegiatan belajar mengajar, masih banyak yang belum mengerjakan tugas yang diberikan oleh guru, serta prestasi dalam perlombaan lomba pada bidang akademik masih kurang. Begitupun dengan lulusan yang diterima pada perguruan tinggi yang berkualitas masih rendah. Dari segi literasi teknologi digital guru, masih banyak guru yang tidak familiar menggunakan teknologi digital dalam kegiatan pembelajaran. Kegiatan manajemen pembelajaran juga belum terlaksana dengan baik seperti pada aspek perencanaan, pelaksanaan, maupun evaluasi pembelajaran.

\section{METODE}

Penelitian ini adalah jenis penelitian expost facto yaitu penelitian kausal komparatif dimana peneliti berusaha mencari tentang hubungan sebab akibat dalam peristiwa tertentu, yang dalam penelitian ini adalah hubungan sebab akibat antara literasi digital dan manajemen pembelajaran terhadap kinerja guru. Dalam penelitian ini peneliti tidak melakukan intervensi secara langsung terhadap variabel bebas. Metode yang digunakan dalam menganalisis data adalah analisis korelasi dan regresi.

\section{Populasi dan Sampel}

Populasi dalam penelitian ini adalah semua guru atau pendidik yang mengajar di SMA Pelita Rantepao sebanyak 33 orang. Guru tersebut terdiri dari Guru Tetap Yayasan, PNS yang diperbantukan, dan Guru Honorer. Menurut Arikunto (2010 :174), sampel adalah sebagian atau wakil dari populasi. Sampel penelitian ini adalah semua populasi mengingat jumlah populasi hanya sedikit

\section{Teknik Analisis Data}

Teknik analisis data yang digunakan dalam penelitian ini adalah teknik analisis statistik deskriptif, korelasi dan regresi linear berganda.

\section{Uji Statistik Deskriptif}

Statistk deskriptif digunakan untuk menganalisa data dengan mendeskripsikan data yang telah terkumpul sebagaimana adanya tanpa bermaksud membuat suatu kesimpulan. Analisis ini bertujuan untuk mengorganisasikan, menganalisis, serta memberikan gambaran secara ringkas dan jelas tentang setiap variabel yang diteliti sehingga memudahkan dalam melihat keterkaitannya masing-masing. Analisis deskriptif ini digunakan untuk menggambarkan minat belajar peserta didik, tingkat literasi digital guru, dan manajemen pembelajaran. Untuk membuat kategori skor minat belajar peserta didik, tingkat literasi digital guru, dan manajemen pembelajaran menggunakan skala lima yaitu pembagian tingkatan yang terdiri atas lima kategori. 
Tabel 1. Rentang Kategori Skor

\begin{tabular}{|c|c|}
\hline Interval Skor & Kategori \\
\hline $0,00-1,00$ & Sangat Rendah \\
\hline $1,01-2,00$ & Rendah \\
\hline $2,01-3,00$ & Sedang \\
\hline $3,01-4,00$ & Tinggi \\
\hline $4,01-5,00$ & Sangat Tinggi \\
\hline
\end{tabular}

Sumber: Sujana (1986)

\section{Analisis Korelasi}

Analisis korelasi bertujuan untuk mengetahui tingkat keeratan hubungan antara variabel X dan Y yang dinyatakan dengan koefisien korelasi. Uji korelasi menggunakan Aplikasi SPSS Versi 25. Apabila nilai signifikansi $<0,05$, maka kedua variabel dianggap memiliki korelasi. Sebaliknya apabila nilai signifikansi $>0,05$, maka kedua variabel tidak memiliki korelasi. Kekuaan hubungan antara dua variabel dapat ditentukan berasarkan derajat hubungan seperti pada Tabel 3.11. berikut ini.

Tabel 2. Pedoman Derajat Hubungan Korelasi

\begin{tabular}{|c|c|c|}
\hline No & Nilai Pearson Correlation & Jenis Korelasi \\
\hline 1 & $0,00-0,20$ & Tidak ada korelasi \\
\hline 2 & $0,21-0,40$ & Korelasi lemah \\
\hline 3 & $0,41-0,60$ & Korelasi sedang \\
\hline 4 & $0,61-0,80$ & Korelasi kuat \\
\hline 5 & $0,81-1,00$ & Korelasi sempurna \\
\hline
\end{tabular}

\section{Analisis Regresi Linear Berganda}

Analisis regresi linear berganda digunakan dalam penelitian ini karena jumlah variabel independennya adalah dua. Adapun persamaan regresi linear berganda sebagai berikut:

$$
\mathrm{Y}=\alpha+\beta 1 x 1+\beta 2 x 2+\varepsilon
$$

Keterangan:

$$
\begin{array}{ll}
\mathrm{Y} & =\text { minat belajar peserta didik } \\
\boldsymbol{x} \mathbf{1} & =\text { literasi digital guru } \\
\boldsymbol{x} 2 & =\text { manajemen pembelajaran } \\
\boldsymbol{\beta 1} & =\text { besar pengaruh X1 terhadap } \mathrm{Y} \\
\boldsymbol{\beta 2} & =\text { besar pengaruh X2 terhadap } \mathrm{Y} \\
\boldsymbol{\alpha} & =\text { konstanta } \\
\boldsymbol{\varepsilon} & =\text { error }
\end{array}
$$

\section{Hipotesis Statistik}

\section{Uji t (Uji Parsial)}

Uji t melakukan pengujian terhadap koefisien regresi secara parsial, pengujian ini dilakukan untuk mengetahui signifikansi peran secara parsial antara variabel independen terhadap variabel dependen 
dengan mengasumsikan bahwa variabel independen lain dianggap konstan. Menurut Sugiyono (2014:250), menggunakan rumus:

$$
\mathrm{t}=\frac{r \sqrt{n-2}}{\sqrt{1-r^{2}}}
$$

Keterangan:

$$
\begin{aligned}
& \mathrm{t}=\mathrm{t}_{\text {hitung }} \\
& \mathrm{r}=\text { koefisien korelasi } \\
& \mathrm{n}=\text { jumlah ke- } \mathrm{n}
\end{aligned}
$$

(t-test) hasil perhitungan ini selanjutnya dibandingkan dengan t tabel dengan menggunakan tingkat kesalahan 0,05 . Kriteria yang digunakan adalah sebagai berikut:

- $\quad \mathrm{H}_{0}$ diterima jika nilai $\mathrm{t}_{\text {hitung }}<\mathrm{t}_{\text {tabel }}$ atau nilai $\operatorname{sig}>\alpha$

- $\quad \mathrm{H}_{0}$ ditolak jika nilai $\mathrm{t}_{\text {hitung }}>\mathrm{t}_{\mathrm{tabel}}$ atau nilai $\operatorname{sig}<\alpha$

Jika $\mathrm{H}_{0}$ diterima maka dapat disimpulkan bahwa tidak terdapat pengaruh signifikan variabel $\mathrm{X}$ terhadap variabel $\mathrm{Y}$, sedangkan bila $\mathrm{H}_{0}$ ditolak artinya terdapat pengaruh yang signifikan variabel $\mathrm{X}$ terhadap variabel $\mathrm{Y}$.

\section{Uji F (Pengujian Secara Simultan)}

Uji F adalah pengujian terhadap koefisien regresi secara simultan. Pengujian ini dilakukan untuk mengetahui pengaruh semua variabel independen yang terdapat di dalam model secara bersama-sama (simultan) terhadap variabel dependen. Uji F dalam penelitian ini digunakan untuk menguji signifikasi pengaruh literasi digital guru dan manajemen pembelajaran secara simultan terhadap Minat Belajar Peserta Didik.

Menurut Sugiyono (2014:257) dirumuskan sebagai berikut:

$$
\mathrm{F}=\frac{R^{2} / k}{\left(1-R^{2}\right) /(n-k-1)}
$$

\section{Keterangan:}

$\mathrm{R}^{2}=$ koefisien determinasi

$\mathrm{k}=$ jumlah variabel independen

$\mathrm{n}=$ jumlah anggota sampel

F hasil perhitungan ini dibandingkan dengan yang diperoleh dengan menggunakan tingkat signifikan level $5 \%$ atau dengan degree freedom $=\mathrm{k}(\mathrm{n}-\mathrm{k}-1)$ dengan kriterian sebagai berikut:

- $\quad \mathrm{H}_{0}$ ditolak jikaF $\mathrm{F}_{\text {hitung }}>\mathrm{F}_{\text {tabel }}$ atau nilai sig $<\alpha$

- $\mathrm{H}_{0}$ diterima jika $\mathrm{F}_{\text {hitung }} \leq \mathrm{F}_{\text {tabel }}$ atau nilai sig $>\alpha$

Jika $\mathrm{H}_{0}$ diterima maka dapat disimpulkan bahwa tidak terdapat pengaruh signifikan variabel $\mathrm{X}$ secara simultan terhadap variabel $\mathrm{Y}$, sedangkan bila $\mathrm{H}_{0}$ ditolak artinya terdapat pengaruh yang signifikan variabel X secara simultan terhadap variabel Y. 


\section{HASIL DAN DISKUSI}

\section{Deskripsi Minat Belajar Peserta Didik di SMA Pelita Rantepao}

Hasil analisis data variabel minat belajar Peserta Didik di SMA Pelita Rantepao secara deskriptif sebagaimana ditunjukkan pada Tabel 3.

Tabel 3. Analisis Deskriptif Minat Belajar Peserta Didik di SMA Pelita Rantepao

\begin{tabular}{|c|c|}
\hline Keterangan & Nilai \\
\hline $\mathrm{N}$ & 33 \\
\hline Mean & 3,94 \\
\hline Range & 1,59 \\
\hline Std. Deviation & 0,37 \\
\hline Maximum & 4,59 \\
\hline Minimum & 3,00 \\
\hline
\end{tabular}

Sumber: Hasil Olah Data

Berdasarkan data pada Tabel 3 di atas diketahui bahwa dari 33 responden yang diteliti melalui pengisian angket yang didistribusikan langsung diperoleh data rata-rata (mean) minat belajar Peserta Didik di SMA Pelita Rantepao sebesar 3,94. Nilai tersebut berada pada kategori “Tinggi”. Data tersebut memberikan informasi bahwa menurut persepsi guru di SMA Pelita Rantepao peserta didik telah memiliki minat yang sudah baik dalam kegiatan pembelajaran. Nilai maksimum yang diperoleh adalah sebesar 4,59 pada kategori "Sangat Tinggi" memberikan gambaran bahwa terdapat peserta didik yang memiliki minat yang sangat tinggi dalam kegiatan pembelajaran. Sedangkan nilai minimum yang diperoleh sebesar 3,00 pada kategori "Sedang" menunjukkan bahwa masih ada peserta didik yang memiliki minat belajar masih berada dibawah rata-rata peserta didik lainnya. Kategori skor minat belajar Peserta Didik di SMA Pelita Rantepao diuraikan pada Tabel 4.4 berikut:

Tabel 4. Kategori Skor Minat Belajar Peserta Didik di SMA Pelita Rantepao

\begin{tabular}{|c|c|c|c|}
\hline Skor & Frekuensi & Persentasi (\%) & Kategori \\
\hline $0,00-1,00$ & 0 & $0 \%$ & Sangat Rendah \\
\hline $1,01-2,00$ & 0 & $0 \%$ & Rendah \\
\hline $2,01-3,00$ & 1 & $3 \%$ & Sedang \\
\hline $3,01-4,00$ & 17 & $52 \%$ & Tinggi \\
\hline $4,01-5,00$ & 15 & $45 \%$ & Sangat Tinggi \\
\hline 1 & 33 & $100 \%$ & \\
\hline
\end{tabular}

Data pada Tabel 4 di atas dapat digambarkan dalam bentuk grafik histogram kategorisasi seperti pada Gambar 1. Berdasarkan hasil analisis data pada tabel 4.4 di atas menunjukkan bahwa Peserta Didik di SMA Pelita Rantepao memiliki minat belajar yang sangat baik yang ditunjukkan oleh skor rata-rata minat belajar sebesar 3,94. Sebanyak 17 responden atau 52\% menyatakan bahwa peserta didik memiliki minat belajar pada kategori “Tinggi” seperti yang ditunjukka oleh grafik paling tinggi pada Gambar 4.1 dan 15 responden lainnya atau 45\% menyatakan bahwa peserta didik memiliki minat belajar pada kategori "Sangat Tinggi". Hanya satu responden lainnya yang menyatakan bahwa minat peserta didik berada pada kategori "Sedang". 


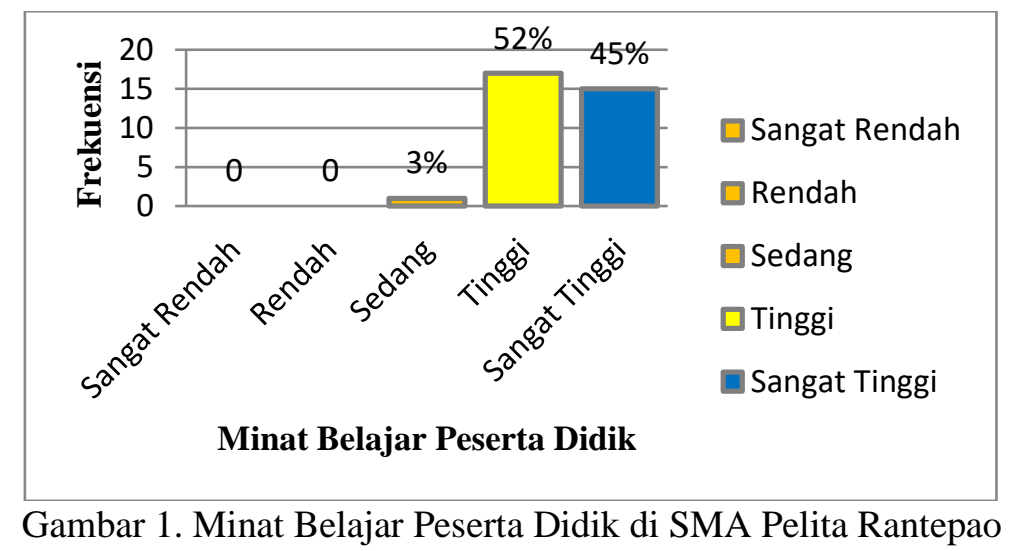

\section{Deskripsi Literasi Digital Guru di SMA Pelita Rantepao}

Hasil analisis data variabel Literasi Digital Guru di SMA Pelita Rantepao secara deskriptif sebagaimana ditunjukkan pada Tabel 5.

Tabel 5. Analisis Deskriptif Literasi Digital Guru di SMA Pelita Rantepao

\begin{tabular}{|c|c|}
\hline Keterangan & Nilai \\
\hline $\mathrm{N}$ & 33 \\
\hline Mean & 4.08 \\
\hline Range & 1.43 \\
\hline Std. Deviation & 0,34 \\
\hline Maximum & 4.62 \\
\hline Minimum & 3.19 \\
\hline
\end{tabular}

Sumber: Hasil Olah Data

Hasil analisis data pada Tabel 5 memberikan gambaran bahwa dari 33 responden yang diteliti melalui pengisian angket yang didistribusikan langsung diperoleh data rata-rata (mean) kemampuan guru pada variabel literasi digital di SMA Pelita Rantepao sebesar 4,08. Angka tersebut apabila dikategorikan berada pada kategori sangat tinggi. Data tersebut memberikan informasi bahwa guruguru di SMA Pelita Rantepao memiliki kemampuan literasi digital yang sangat baik. Nilai maksimum yang diperoleh adalah sebesar 4.62 memberikan gambaran bahwa terdapat guru yang memiliki kemampuan literasi digital yang lebih tinggi dari rata-rata kemampuan guru lainnya. Sedangkan nilai minimum yang diperoleh sebesar 3,19 menunjukkan bahwa masih ada guru yang memiliki kemampuan literasi digital yang lebih rendah dari kemampuan rata-rata guru pada umumnya.

Kategori skor literasi digital guru SMA Pelita Rantepao yang menjadi sampel dalam penelitian ini duraikan pada Tabel 6. berikut:

Tabel 6. Kategori Skor Literasi Digital Guru di SMA Pelita Rantepao

\begin{tabular}{|c|c|c|c|}
\hline Skor & Frekuensi & Persentasi (\%) & Kategori \\
\hline $0,00-1,00$ & 0 & $0 \%$ & Sangat Rendah \\
\hline $1,01-2,00$ & 0 & $0 \%$ & Rendah \\
\hline $2,01-3,00$ & 0 & $0 \%$ & Sedang \\
\hline $3,01-4,00$ & 13 & $39 \%$ & Tinggi \\
\hline 4,01-5,00 & 20 & $61 \%$ & Sangat Tinggi \\
\hline Jumlah & 33 & $100 \%$ & \\
\hline
\end{tabular}


Data pada Tabel 6 dapat disajikan dalam bentuk grafik histogram pada Gambar 2 berikut ini:

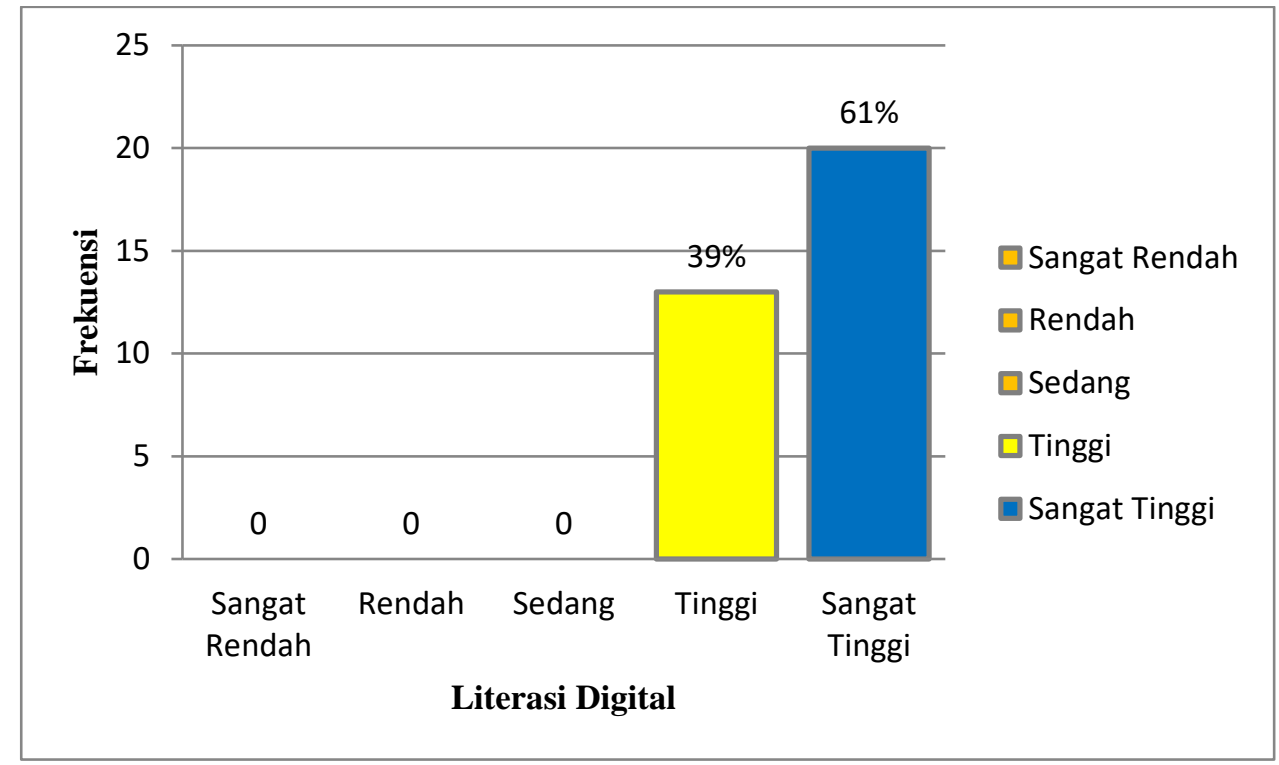

Gambar 2. Grafik Literasi Digital Guru di SMA Pelita Rantepao

Berdasarkan data pada Tabel 6 di atas menunjukkan bahwa dari 33 responden yang diteliti, frekuensi guru yang memiliki kemampuan literasi digital pada kategori "sangat tinggi” adalah sebanyak 20 orang atau $61 \%$ yang ditunjukkan oleh grafik paling tinggi pada Gambar 4.2 di atas. Sedangkan 13 guru lainnya atau 39\% berada pada kategori "tinggi" seperti yang ditunjukkan oleh grafik. Tidak ada guru yang berada pada kategori "sedang" atau lebih rendah.

\section{Deskripsi Manajemen Pembelajaran Guru di SMA Pelita Rantepao}

Hasil analisis data variabel manajemen pembelajaran yang dilakukan oleh Guru di SMA Pelita Rantepao secara deskriptif terlampir pada lampiran sebagaimana ditunjukkan pada Tabel 4.7.

Tabel 7. Analisis Deskriptif Manajemen Pembelajaran Guru di SMA Pelita Rantepao

\begin{tabular}{|c|c|}
\hline Keterangan & Nilai \\
\hline $\mathrm{N}$ & 33 \\
\hline Mean & 4,20 \\
\hline Range & 0,84 \\
\hline Std. Deviation & 0,23 \\
\hline Maximum & 4,67 \\
\hline Minimum & 3,83 \\
\hline
\end{tabular}

Sumber: Hasil Olah Data

Berdasarkan data pada Tabel 7 di atas diketahui bahwa dari 33 responden yang diteliti melalui pengisian angket yang didistribusikan langsung diperoleh data rata-rata (mean) kemampuan manajemen pembelajaran yang dilakukan oleh guru di SMA Pelita Rantepao sebesar 4,20. Nilai rata-rata tersebut berada pada kategori "Sangat Tinggi". Data tersebut memberikan informasi bahwa guru-guru di SMA Pelita Rantepao telah mampu melakukan manajemen pembelajaran dengan sangat baik. Nilai maksimum yang diperoleh adalah sebesar 4,67 memberikan gambaran bahwa terdapat guru yang memiliki kemampuan manajemen pembelajaran yang lebih tinggi dari rata-rata kemampuan manajemen 
pembelajaran guru lainnya. Sedangkan nilai minimum yang diperoleh sebesar 3,83 menunjukkan bahwa masih ada guru yang memiliki kemampuan sedang pada aspek tersebut.

Kategori skor manajemen pembelajaran yang dilakukan oleh Guru di SMA Pelita Rantepao diuraikan pada Tabel 8 berikut:

Tabel 8. Kategori Skor Manajemen Pembelajaran Guru di SMA Pelita Rantepao

\begin{tabular}{|c|c|c|c|}
\hline Skor & Frekuensi & Persentasi $(\%)$ & Kategori \\
\hline $0,00-1,00$ & 0 & $0 \%$ & Sangat Rendah \\
\hline $1,01-2,00$ & 0 & $0 \%$ & Rendah \\
\hline $2,01-3,00$ & 0 & $0 \%$ & Sedang \\
\hline $3,01-4,00$ & 9 & $27 \%$ & Tinggi \\
\hline $4,01-5,00$ & 24 & $73 \%$ & Sangat Tinggi \\
\hline Jumlah & 33 & $100 \%$ & \\
\hline
\end{tabular}

Data pada Tabel 8 di atas dapat digambarkan dalam bentuk grafik histogram kategorisasi pada Gambar 3 berikut ini:

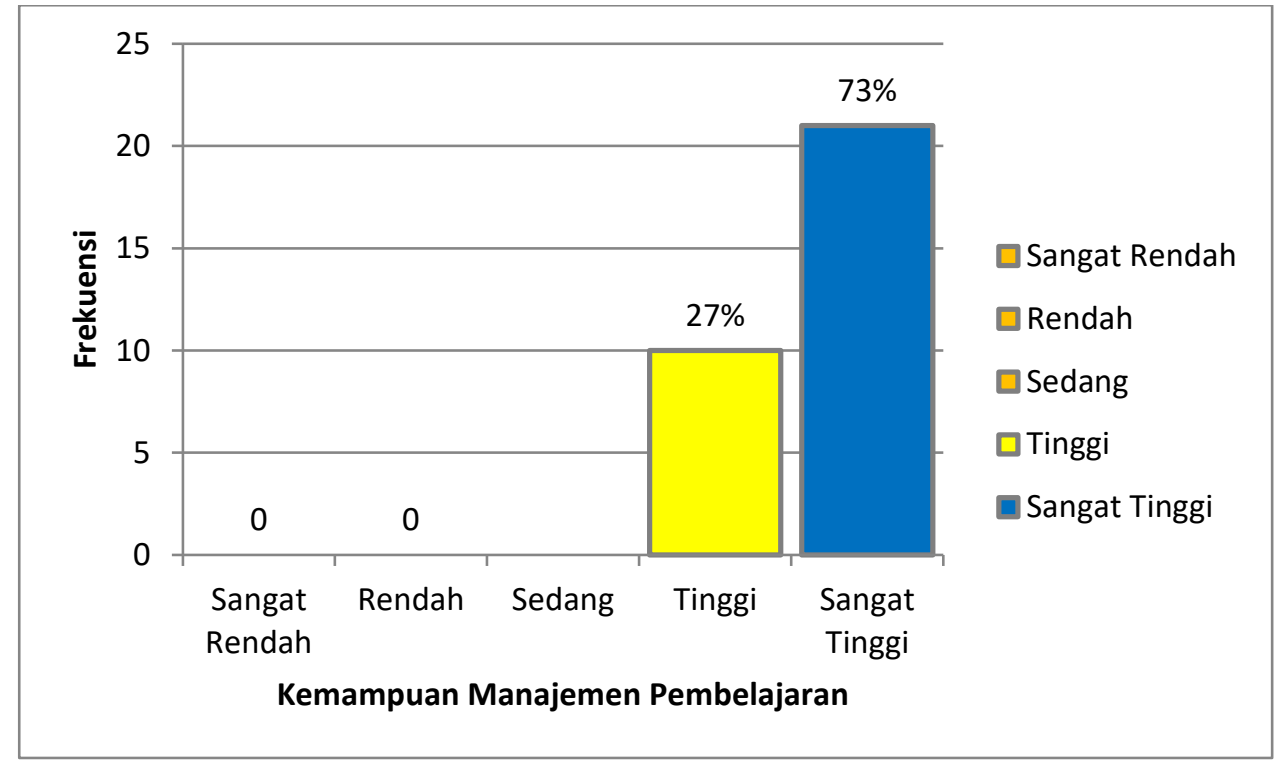

Gambar 3. Manajemen Pembelajaran Guru di SMA Pelita Rantepao

Berdasarkan data pada Tabel $4.8 \mathrm{di}$ atas diketahui bahwa skor rata-rata Manajemen Pembelajaran sebesar 4,20 berada pada rentang 4,01-5,00 yaitu pada kategori "Sangat Tinggi". Frekuensi manajemen pembelajaran pada kategori "Sangat Tinggi” sebanyak 24 orang atau $73 \%$ seperti yang ditunjukkan oleh grafik paling tinggi pada Gambar 4.2 di atas. Sedangkan 9 orang lainnya atau $27 \%$ berada pada kategori "Tinggi". Tidak ada responden yang menempati kategori "Sedang" atau kategori yang lebih rendah.

\section{Uji Korelasi}

Uji korelasi dimaksudkan untuk mengetahui tingkat kekuatan hubungan antar variabel dengan menggunakan Korelasi Product Moment. Analisis Korelasi Product Moment digunakan untuk 
mengetahui korelasi antara satu variabel dengan variabel lainnya dengan kategori data ordinal. Dalam penelitian ini pengujian dilakukan dengan bantuan aplikasi SPSS versi 25.

Dasar pengambilan keputusannya adalah apabila nilai signifikansi yang diperoleh $<0,05$, maka kedua variabel dianggap memiliki korelasi. Sebaliknya apabila nilai signifikansi $>0,05$, maka kedua variabel tidak memiliki korelasi. Hasil uji korelasi ketiga variabel dalam penelitian ini disajikan pada Tabel 9 berikut ini:

Tabel 9. Matriks Korelasi Variabel Literasi Digital, Manajeen Pembelajaran dan Minat Belajar Peserta Didik

\begin{tabular}{|l|l|c|c|c|}
\hline \multicolumn{2}{|l|}{ Variabel } & $\begin{array}{c}\text { Literasi } \\
\text { digital }\end{array}$ & $\begin{array}{c}\text { Manajemen } \\
\text { Pembelajaran }\end{array}$ & $\begin{array}{c}\text { Minat } \\
\text { Belajar }\end{array}$ \\
\hline \multirow{2}{*}{ Literasi digital } & $\begin{array}{l}\text { Pearson } \\
\text { Corelation }\end{array}$ & & 0,597 & 0,765 \\
\cline { 2 - 5 } & Sig. (2-tailed) & & 0,000 & 0,000 \\
\hline \multirow{2}{*}{$\begin{array}{l}\text { Manajemen } \\
\text { Pembelajaran }\end{array}$} & $\begin{array}{l}\text { Pearson } \\
\text { Corelation }\end{array}$ & 0,597 & & 0,678 \\
\cline { 2 - 5 } Minat Belajar & Sig. (2-tailed) & 0,000 & & 0,000 \\
\hline \multirow{2}{*}{$\begin{array}{l}\text { Pearson } \\
\text { Corelation }\end{array}$} & 0,765 & 0,678 & \\
\cline { 2 - 5 } & Sig. (2-tailed) & 0,000 & 0,000 & \\
\hline
\end{tabular}

Sumber: Hasil olahan SPSS

Berdasarkan data pada Tabel 9 di atas diperoleh nilai signifikansi antara variabel literasi digital dengan variabel manajemen pembelajaran $0,00<0,05$ sehingga dapat disimpulkan bahwa ada korelasi antara variabel literasi digital dengan varabel manajemen pembelajaran. Nilai Korelasi Pearson sebesar 0,597 menunjukkan bahwa kekuatan korelasinya adalah "sedang". Pada variabel literasi digital dan variabel minat belajar diperoleh nilai signifikansi sebesar $0,00<0,05$ sehingga dapat disimpulkan bahwa terdapat korelasi antara kedua variabel. Nilai Korelasi Pearson sebesar 0,765 menunjukkan bahwa korelasinya kuat. Sedangkan nilai signifikansi pada variabel manajemen pembelajaran dengan variabel minat belajar sebesar $0,00<0,05$ menunjukkan bahwa terdapat korelasi antara kedua variabel. Nilai Korelasi Pearson sebesar 0,678 menunjukkan bahwa korelasinya kuat.

\section{Uji Regresi Linear Berganda}

Untuk mengui pengaruh variabel literasi digital (X1) dan manajemen pembelajaran (X2) terhadap variabel $\mathrm{Y}$ dalam penelitian ini menggunakan analisis regresi berganda. Model regresi disajikan dalam Tabel 4.12 berdasarkan output SPSS sebagai berikut:

Tabel 10. Hasil Perhitungan Regresi Linear Berganda X1 dan X2 terhadap Y

\begin{tabular}{|c|l|c|c|c|c|c|}
\hline \multirow{2}{*}{\multicolumn{2}{|c|}{ Model }} & \multicolumn{2}{|c|}{$\begin{array}{c}\text { Unstandardized } \\
\text { Coefficients }\end{array}$} & $\begin{array}{c}\text { Standardized } \\
\text { Coefficients }\end{array}$ & \multirow{2}{*}{$t$} & \multirow{2}{*}{ Sig. } \\
\cline { 3 - 5 } \multicolumn{2}{|c|}{} & B & Std. Error & Beta & & \\
\hline \multirow{2}{*}{1} & (Constant) & $-0,847$ & 0,724 & & $-1,170$ & 0,251 \\
\cline { 2 - 7 } & Literasi Digital Guru & 0,604 & 0,143 & 0,560 & 4,223 & 0,000 \\
\hline
\end{tabular}




\begin{tabular}{|l|l|c|c|c|c|c|}
\hline $\begin{array}{l}\text { Manajemen } \\
\text { Pembelajaran }\end{array}$ & 0,556 & 0,214 & 0,334 & 2,592 & 0,015 \\
\hline \\
Dependent Variable: Minat Belajar Peserta Didik \\
Sumber: Hasil olahan SPSS
\end{tabular}

Berdasarkan Tabel 10 di atas dapat dibuat model regresi berganda sebagai berikut:

$$
\begin{aligned}
& \hat{Y}=\alpha+\beta 1 X 1+\beta 2 X 2 \\
& \hat{Y}=-0,847+0,604 X_{1}+0,556 X_{2}
\end{aligned}
$$

Berdasarkan persamaan regresi di atas diuraikan maknanya sebagai berikut:

a. Nilai konstanta atau $\alpha$ sebesar $-0,847$ yang berarti jika nilai literasi digital guru (X1) dan manajemen pebelajaran (X2) masing-masing sebesar 0, maka nilai kinerja guru (Y) sebesar -0,847.

b. Nilai $\beta 1$ atau nilai koefisien regresi literasi digital guru (X1) sebesar 0,604 yang berarti jika nilai literasi digital guru (X1) mengalami kenaikan 1 dan variabel manajemen pembelajaran (X2) tetap, maka nilai minat belajar siswa (Y) akan meningkat sebesar 0,604. Nilai koefisien regresi literasi digital (X1) bernilai positif berarti terdapat hubungan positif antara variabel literasi digital (X1) dengan variabel minat belajar peserta $\operatorname{didik}(\mathrm{Y})$.

c. Nilai $\beta 2$ atau nilai koefisien regresi manajemen pembelajarann (X2) sebesar 0,556 yang berarti jika nilai manajemen pembelajaran (X2) mengalami kenaikan 1 dan variabel literasi digital (X1) tetap, maka nilai minat belajar siswa (Y) akan meningkat sebesar 0,556. Nilai koefisien regresi manajemen pembelajaran (X2) bernilai positif berarti terdapat hubungan positif antara variabel manajemen pembelajaran (X2) dengan variabel minat belajar peserta didik (Y).

Untuk mengetahui besarnya sumbangan variabel literasi digital (X1) dan manajemen pembelajarann (X2) secara bersama-sama mempengaruhi variabel minat belajar peserta didik (Y) dapat dilihat pada Tabel 4.13 sebagai berikut:

Tabel 11. Koefisien Determinasi Literasi Digital (X1) dan Manajemen Pembelajaran (X2) terhadap Minat Belajar Peserta Didik (Y)

\begin{tabular}{|c|c|c|c|c|}
\hline Model & $\mathrm{R}$ & $\mathrm{R}$ Square & Adjusted $\mathrm{R}$ Square & Std. Error of the Estimate \\
\hline 1 & $0,813^{\mathrm{a}}$ & 0,661 & 0,638 & 0,22113 \\
\hline
\end{tabular}

a. Predictors: (Constant), Manajemen Pembelajaran, Literasi Digital

Sumber: Hasil olahan SPSS

Dari tabel 11 diperoleh nilai R Square atau nilai koefisien determinasi sebesar 0,661 yang berarti $66,1 \%$ variabel literasi digital dan manajemen pembelajaran secara bersama-sama berpengaruh terhadap variabel minat belajar siswa.

\section{Diskusi}

\section{Literasi Digital Guru di SMA Pelita Rantepao}

Berdasarkan hasil analisis deskriptif data variabel kemampuan literasi digital guru di atas mengindikasikan bahwa guru-guru di SMA Pelita Rantepao telah memiliki tingkat literasi digital yang 
baik. Hal itu dapat dilihat dari kemampuan mereka menggunakan perangkat digital serta mampu memberikan evaluasi terhadap setiap konten yang diperoleh baik dari situs di internet, media sosial, atau media digital lainnya. Hasil penelitian menunjukkan bahwa mereka sangat sering menggunakan berbagai macam perangkat digital seperti smartphone, tablet, laptop, PC, atau perangkat digital lainnya. Guru menggunakan smartphone terutama untuk kegiatan berkomunikasi dan mengakses konten-konten di internet. Mereka juga telah mampu melakukan pengetikan dengan aplikasi Microsoft Word untuk berbagai tujuan misalnya dalam membuat perangkat pembelajaran, mencetak dokumen, atau menyalin data dari suatu perangkat. Keterampilan teknis literasi digital guru dapat dilihat dari kemampuannya berselancar di internet, mampu memanfaatkan fitur-fitur yang tersedia pada aplikasi teknologi digital, mampu memanfaatkan layanan yang tersedia di internet untuk mendukung cara berpikir kritis, menumbuhkan kreatifitas dalam pembelajaran, dan membuat inovasi pembelajaran.

Teknologi digital sangat membantu guru dalam menyampaikan materi ajar dengan cepat dan efisin. Materi pelajaran yang telah disusun dapat dengan mudah didistribusikan kepada peserta didik melalui berbagai aplikasi misalnya e-mail, whatsapp, messenger, telegram atau bahkan melalui pertemuan secara virtual dengan bantuan aplikasi zoom, google meet, atau aplikasi sejenisnya. Siswa akan lebih cepat mendapatkan informasi materi pelajaran kapan dan dimana saja selama mereka dapat mengakses internet. Para guru juga dapat menjangkau peserta didik dengan mudah dan cepat sehingga menghemat waktu dan biaya, secara khusus dalam menyelenggarakan pembelajaran dari rumah pada masa pandemi Covid-19 saat ini. Selain itu antara guru yang satu dengan guru yang lain dapat berbagi bahan ajar dengan cepat. Sedangkan untuk kepentingan analisis penilaian/evaluasi pelajaran yang objektif, akuntabel, dan cepat guru-guru dapat menggunakan aplikasi pengolah angka misalnya Microsoft Excel atau aplikasi sejenis.

Kemudahan dalam menyebarkan ataupun memperoleh informasi melalui teknologi digital disatu sisi menuntut seorang guru bijak melakukan evaluasi terhadap setiap konten yang ada. Guru di SMA Pelita secara aktif membimbing peserta didik untuk memilah-milah materi yang diperoleh dari internet, mencari data dari sumber yang valid dan dapat dipercaya serta membandingkannya dengan informasi dari sumber-sumber lain sehingga data dan informasi yang diperoleh menjadi lebih akurat dan tidak menyesatkan. Guru juga memberikan pemahaman akan dampak buruk apabila mengakses kontenkonten yang tidak pantas atau mengkonsumsi suatu informasi begitu saja tanpa menganalisa kebenarannya terlebih dahulu. Menurut Sitohang (2020) bahwa penggunaan teknologi informasi yang tidak bijak akan berdampak buruk bagi peserta didik khususnya pada aspek pembentukan karakter. Dengan kemudahan akses data dan informasi memungkinkan pihak tertentu untuk menyebarkan kontenkonten yang dapat menyesatkan, memprovokasi, menimbulkan kebencian, dan beragam konten negatif lainnya.

\section{Pengaruh Literasi Digital terhadap Minat Belajar Peserta Didik}

Berdasarkan hasil anaisis data dengan menggunakan Uji-t di atas diperoleh hasil bahwa Tingkat Literasi Digital Guru di SMA Pelita Rantepao berpengaruh secara signifikan terhadap Minat Belajar 
Peserta Didik. Guru yang memiliki literasi digital yang baik cenderung dapat meningkatkan minat belajar dari peserta didik. Guru-guru di SMA Pelita Rantepao telah mampu menemukan dan memanfaatkan konten digital dengan baik. Perangkat digital yang mereka miliki atau yang tersedia d sekolah digunakan secara maksimal dalam mendukung kegiatan pembelajaran. Sekolah telah berusaha melengkapi sarana dan prasarana pendukung seperti PC, proyektor, printer, jaringan internet dan perangkat pendukung lainnya. Sebagaimana penelitian yang dilakukan oleh Durriyah (2018:53) menemukan fakta bahwa guru yang menjadi pengguna aktif teknologi digital tidak gugup dalam menggunakan perangkat tersebut dalam kegiatan pembelajaran. Penelitian Borthwick (2017:46) juga mengemukakan bahwa bahwa U.S. Department of Education's Office of Educational Technology (OET) menemukan fakta bahwa guru-guru yang memiki kemampuan dan keterampilan yang baik dalam menggunakan teknologi mampu mendisain kegiatan pembelajaran menjadi lebih kreatif, produktif dan terbiasa dalam memecahkan masalah. Peserta didik yang memasuki kelas berharap bertemu dengan pendidik yang dapat memanfaatkan teknologi untuk mengubah pembelajaran menjadi penuh tantangan dan menyengkan. Pendapat ini menekankan bahwa guru harus memahami karakter peserta didik dan mampu menyelenggarakan pembelajaran sesuai dengan kebutuhan mereka. Kita tidak ingin guru mengajar para generasi milenial dengan cara-cara konvensional yang dapat menyebabkan para peserta didik belajar dalam suasana keterasingan sehingga menimbulkan kesan bahwa apa yang disampaikan oleh guru sebagai sesuatu yang sudah usang dan mengurangi minat mereka dalam belajar.

Sekolah berusaha melengkapi sarana dan prasarana pendukung yang dapat dimanfaatkan baik oleh pendidik, peserta didik, ataupun tenaga kependidikan yang sangat membutuhkannya. Selain itu sekolah juga memfasilitasi bimbingan dan latihan bagi guru dalam pemanfaatan teknologi digital dengan tujuan memberikan pembekalan yang cukup bagi guru sehingga mereka menjadi lebih percaya dri dalam menggunakan media digital dalam proses pembelajaran.

Hasil penelitian menunjukkan bahwa masih terapat beberapa guru yang membutuhkan latihan dan bimbingan terutama dalam penyusunan dan penggunaan bahan presentasi pembelajaran. Hasil penelitian yang sama juga dikemukakan oleh Wei Wang, Denise Schmidt-Crawford dan Yi Jin (2018: 234) bahwa beberapa guru memiliki pengetahuan yang masih rendah dalam penerapan teknologi digital untuk mendukung kegiatan pembelajaran. Hal ini tentu menjadi perhatian serius bagi sekolah untuk memfasilitasi guru dalam meningkatkan keterampilannya, seperti menyelenggarakan kegiatan pelatihan pada aspek keterampilan penggunaan perangkat digital dalam pembelajaran minimal satu kali setiap semester. Menurut Sitohang (2020), bahwa "guru yang profesional harus mampu melaksanakan pembelajaran yang menginsiprasi siswa sehingga terbentuk kemapuan berpikir kreatif, kritis, dan inovatif dengan pola pembelajaran to describe, to explain, to illustrate, to demonstrate”. Pembelajaran tidak sekedar berorientasi pada hasil yang dicapai tetapi juga menyangkut proses dari kegiatan pembelajaran. Guru tidak hanya sekdar mentransfer suatu pengetahuan kepada setiap peserta didik tetapi guru harus membimbing mereka untuk membangun sendiri pengetahuan di dalam benak mereka. 
Didalam diri setiap individu terdapat potensi masing-masing yang harus digali dan dikembangkan sesuai dengan karakter masing-masing.

\section{Pengaruh Literasi Digital dan Manajemen Pembelajaran terhadap Minat Belajar Peserta Didik}

Berdasarkan temuan penelitian menunjukkan bahwa literasi digital dan manajemen pembelajaran berpengaruh secara bersama-sama terhadap minat belajar peserta didik. Guru yang memiliki tingkat literasi digital yang baik dapat mengakses sumber belajar dan pegetahuan baru dengan mudah sehingga dapat mengikuti perkembangan terkini dengan cepat. Selain itu keterampilan menggunakan teknologi digital yang baik dapat membantu guru dalam melakukan perencanaan, pelaksanaan, dan evaluasi pembelajaran dengan baik. Dengan bantuan alat-alat teknologi yang baik maka guru dapat mengakses ragam informasi yang mendukung perencanaan pembelajaran yang matang. Demikian juga dengan pelaksanaan pembelajaran, apabila guru menggunakan metode, dan media yang tepat serta menguasai materi pembelajaran maka hal itu akan meningkatkan minat belajar peserta didik. Hal itu dapat kita lihat dari hasil penelitian ini menunjukkan bahwa guru-guru di SMA Pelita Rantepao memiliki tingkat literasi digital yang baik dan mampu melaksanakan manajemen pembelajaran dengan baik sehingga minat belajar peserta didik di SMA Pelita Rantepao juga berada pada kategori yang baik.

\section{KESIMPULAN}

Literasi digital guru mempengaruhi minat belajar peserta didik di SMA Pelita Rantepao Kabupaten Toraja Utara. Besar pengaruh literasi digital guru berpengaruh terhadap minat belajar peserta didik sebesar 0,604 atau 60,4\%. Pengaruh variabel literasi digital lebih besar dibandingkan dengan manajemen pembelajaran terhadap minat belajar peserta didik. Model yaitu literasi digital dan manajemen pembelajaran dapat menjelaskan variasi pada minat belajar peserta didik. Model (X1 dan $\mathrm{X} 2)$ dapat menjelaskan variasi Y sebesar $66,1 \%$

\section{REFERENSI}

Arikunto, S. (2010). Prosedur Penelitian Suatu Pendekatan Praktik. Jakarta: Rineka Cipta.

Baran, S. dan Davis, D. (2010). Mass Communication Teory: Foundations, Frement and Future. (Terj. Alfrianto Daud dan Putri). Jakarta: Salemba Humanika.

Borthwick, Arlene C. dan Randall Hansen. (2017). Digital Literacy in Teacher Education: Are Teacher Educators Competent? Jurnal. National College of Education, National Louis University in Chicago. U.S.: Taylor \& Francis Online. Sumber: https://doi.org/10.1080/21532974.2017.1291249

Durriyah, Tati Lathipatud dan Muhammad Zuhdi. (2018). Digital Literacy with EFL Student Teachers: Exploring Indonesian Student Teachers' Initial Perception About Integrating Digital Technologies into a Teaching Unit. Junal. Fakultas Ilmu Tarbiyah dan Keguruan. Universitas Islam Negeri Syarif Hidayatullah Jakarta. Indonesia: Australian International Academic Centre PTY.LTD. Sumber: http://dx.doi.org/10.7575/aiac.ijels.v.6n.3p.53. 
Francis, James. (2017). The Effects of Technology on Student Motivation and Engagement in Classroom-

Based Learning. Thesis. Universitas New England. Sumber: http://dune.une.edu/theses/121

Haryati, et.al. (2019). Analisis Minat Belajar dan Kemampuan Awal Keterampilan Berpikir Kritis

Siswa pada Materi Minyak Bumi. Dalam Jurnal Pijar MIPA, Vol. 14 No. 3. Sumber: http://dx.doi.org/10.29303/jpm.v14i3.1297

Hidayat, et.al .(2016). Studi Integrasi Tik Dalam Pembelajaran di Sekolah Menengah Kejuruan. Jurnal.

Sumber: http://dx.doi.org/10.17977/jp.v1i12.8228

Hidayatullah, S dan Abdul Waris, Riezky Chris Devianti. (2018). Perilaku Generasi Milenial dalam

Menggunakan Aplikasi Go-Food. Jurnal Manajemen dan Kewirausahaan Vol 6 No. 2 (2018).

Sumber. https://doi.org/10.26905/jmdk.v6i2.2560

Kemdikbud. (2016). Permendikbud No. 22 Tahun 2016 tentang Standar Proses Pendidikan Dasar dan

Menengah. Sumber: https://jdih.kemdikbud.go.id/

Kemdikbud. (2014). Permendikbud Nomor $103 \quad$ Tahun 2014.

Sumber: https://jdih.kemdikbud.go.id/

Kemdikbud. 2007. Permendiknas No. 16 Tahun 2007. Standar Kualifikasi Akademik dan Kompetensi

Guru. Sumber: https://jdih.kemdikbud.go.id/

Kemdikbud. 2005. Permendikbud Nomor 14 Tahun 2005 tentang Guru dan Dosen. Sumber: https://jdih.kemdikbud.go.id/

Kydd, Lesley. Megan Crawford dan Colin Riches. (2004). Profesional Development for Education Management (Pengembangan Profesional untuk Manajemen Pendidikan). Penerjemah: Unsula Gyani. Jakarta: Grasindo.

Rozikin, dkk. (2018). Hubungan Minat Belajar Siswa dengan Prestasi Belajar Siswa pada Mata Pelajaran Kimia di SMA Negeri 1 Tebat Karai dan SMA Negeri 1 Kabupaten Kepahiang. Dalam Jurnal Pendidikan dan Ilmu Kimia, 2018:2(1). Sumber: https://ejournal.unib.ac.id/index.php/alotropjurnal/article/viewFile/4740/2599

Sirait, Erlando D. (2016). Pengaruh Minat Belajar terhadap Prestasi Belajar Matematika. Jurnal Formatif 6(1): 35-43. Sumber: https://journal.lppmunindra.ac.id/index.php/Formatif/article/view/750/659

Slamet, et.al. 2017. Manajemen Pembelajaran Berbasis Kurikulum 2013 di Smp Islam Kota Semarang (Studi Empiris di Smp Sub Rayon 02 Kota Semarang). Jurnal Educational Management EM 6 (2) (2017) 115 - 122. Sumber: https://journal.unnes.ac.id/sju/index.php/eduman/article/view/22776

Styaningrum, Amalia (2016). Analisis Hambatan Guru Dalam Pengintegrasian Teknologi Di SMPN 1 Grabag. Artikel.

Sumber: https://repository.uksw.edu/bitstream/123456789/10781/2/T1_702011130_Full\%20text.pdf

Sugiyono. (2014). Metode Penelitian Pendidikan Pendekatan Kuantitatif, Kualitatif, dan R\&D. Bandung: Alfabeta.

Unesco. (2018_. UNESCO ICT Competency Framework for Teachers. Sumber: https://unesdoc.unesco.org/ark:/48223/pf0000265721. Diakses : 15 Mei 2020 
Wang, Wei. Denise Schmidt-Crawford dan Yi Jin. (2019). Preservice Teachers' TPACK Development: A Review of Literature. Jurnal. Iowa State University and Kennesaw State University. U.S.: Taylor \& Francis Online. Sumber: https://doi.org/10.1080/21532974.2018.1498039

Websindo.com. (2019). Indonesia Digital 2019: Tinjauan Umum. Website: https://websindo.com/indonesia-digital-2019-tinjauan-umum/ 